\title{
INTERPLAY BET WEEN THE IMMUNOHISTOCHEMICAL EXPRESSION OF P53 AND THE PROLIFERATION INDEX IN THE KERATINOCYTE TUMORS OF THE SKIN
}

Milena Rakocevic ${ }^{1}$, Biljana Popovska Jovicic ${ }^{2}$, Tomislav Jocic ${ }^{3}$, Stevan Matic ${ }^{1}$, Goran Azanjac ${ }^{4}$, Nemanja Jovicic ${ }^{5}$, Vesna Stankovic ${ }^{1,4}$, Snezana Jancic ${ }^{1}$

${ }^{1}$ Department of Pathology, Faculty of Medical Sciences, University of Kragujevac, Kragujevac, Serbia

${ }^{2}$ Department of Infectious diseases, Faculty of Medical Sciences, University of Kragujevac, Kragujevac, Serbia

${ }^{3}$ Department of Pathology, General Hospital Pirot, Pirot, Serbia

${ }^{4}$ Clinical Center Kragujevac, Kragujevac, Serbia

${ }^{5}$ Department of Histology and Embryology, Faculty of Medical Sciences, University of Kragujevac, Kragujevac, Serbia

\section{UZAJAMNO DEJSTVO IZMEDU IMUNOHISTOHEMIJSIKE EISPRESIJE P53 I INDEKSA PROLIFERACIJE U KERATINOCITNIM TUMORIMA KOŽE}

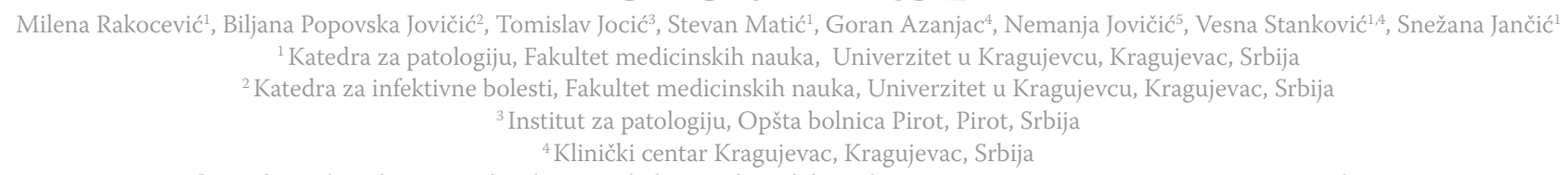

\begin{abstract}
P53 is important for cell cycle regulation, and its overexpression is seen in malignant tumors. We examined correlation between $p 53$ expression and cell proliferation, and its role in the pathogenesis of keratinocyte skin tumors. We used biopsies from patients with squamous cell carcinoma, actinic keratosis and keratoacanthoma. We examined crosssections stained with HE and using anti-cytokeratin, antip53 and anti-Ki67 antibodies.

Expression of $p 53$ is found in $87,85 \%$ of SCC, in $83.3 \%$ of $A K$ and $13.4 \% \mathrm{KA}$. The high index of $p 53$ expression was higher in SCC and AK compared to KA. We also observed a positive correlation between the expression of $p 53$ and localization of the tumors. The largest proportion of subjects with $A K$ and SCC has a high index of $p 53$ expression on photoexposed region. We also observed that $p 53$ expression correlates with age whereby in $A K p 53$ expression increases with age. The high index of proliferation is most frequent in SCC and KA. Also at AK we found a strong correlation between a moderate proliferation index and tumor localization in photoexposed region. Between the proliferation index and $p 53$ expression we observed a significant positive correlation only in SCC.

Proliferation index and the expression of $p 53$ are useful for the differentiation of precursor keratinocyte lesions and skin carcinoma. High p53 expression has been associated with the aging and significantly correlates with the exposure to $U V$ radiation in $S C C$ and $A K$. High expression of $p 53$ in $A K$ and SCC supports the importance of this oncoprotein in carcinogenesis of the skin.
\end{abstract}

Keywords: Keratinocyte tumours, p53 expression, proliferative index, immunohistochemistry

\section{SAŽETAK}

Protein 53 je značajan za regulaciju ćelijskog ciklusa i njegova pojačana ekspresija se viđa kod malignih tumora. Naš cilj je ispitivanje povezanosti ekspresije $p 53$ sa proliferacijom ćelija $i$ ispitivanje njegove uloge u patogenezi keratinocitnih tumora kože. Korišćen je biopsijski operativni materijal skvamocelularnog karcinoma (SCC), aktiničničnih keratoza (AK) $i$ keratoakantoma. Na presecima debljine $4 \mu m$, su primenjene rutinska $H E i$ imunohistohemijska $A B C$ metoda sa anti-cytokeratin, anti-p53 $i$ anti- Ki67 antitelima.

Ekspresija p53 je nadena u 87, 85 SCC, u 83. 3\% AK i u 13. $4 \% \mathrm{KA}$, pri čemu je visok indeks ekspresije p53 značajno češći u SCC i AK u odnosu na KA. Takode je uočena pozitivna korelacija izmedu ekspresije p53 i lokalizacje tumora. Statistički značajno najviše ispitanika sa SCC i AK ima visok indeks ekspresije p53 na fotoeksponiranoj reiji. Zapažena je znajana povzanost ekspresije p53 sa starošću ispitanika, pri čemu u AK sa godinama raste i ekspresija p53. Visok indeks proliferacije je najčešći u SCC $i$ KA, dok je u AK nadena jaka korelacija izmedu umerenog indeksa proliferacije i lokalizacije tumora na fotoeksponiranoj regiji (Spearman's corelation $p=0.025)$. Iznedu proliferativnog indeksa i ekspresije $p 53$ je zapažena značajna pozitivna koreleacija samo u SCC ( $p<0.05 p=0.028$; Spearman's rho 0, 377)

Indeks proliferacije i ekspresija p53 su korisni za razlikovanje prekursorskih keratinocitnih lezija od karcinoma kože. Prekomerna ekspresija p53 je povezana sa procesom starenja i u značajnoj je korelaciji sa izlaganjem UV zračenju u SCC i AK. Visoka ekspresija p53 u AK i SCC podržava značaj ovog onkoproteina u karcinogenezi kože.

Ključne reči: keratinocitni tumori, ekspresija p53, proliferativni indeks, imunohistohemija 


\title{
ABBREVIATIONS
}

\author{
SCC - squamous cell carcinoma, AK - actinic keratosis \\ KA - keratoacanthoma
}

\section{INTRODUCTION}

Keratinocyte skin cancers are clinically and histopathologically heterogeneous group of lesions, caused by the proliferation of epidermal and adnexal keratinocyte. On the one side of the keratinocyte spectrum are a number of benign proliferation, whilst at the other end are malignant tumors which, not infrequently, have aggressive course with metastatic potential, such as squamous cell carcinoma $(1,2)$. Actinic keratosis also belongs to this keratinocyte spectrum (1). At the same time, keratinocyte tumors are the largest group of tumors of the skin, which is associated with these extreme fluctuations of climatic and meteorological factors, depletion of the ozone layer, ultraviolet and ionizing radiation $(3,4,5)$. In addition to ultraviolet radiation, ionizing radiation and thermal damage to the chronic, frequent exogenous carcinogens are cigarette smoking, human papilloma virus, arsenic, vinyl chloride, polycyclic aromatic hydrocarbons, insecticides, herbicides, cadmium, etc. (6).

About $20 \%$ of keratinocyte skin cancers represents squamous cell carcinoma, which is the second most frequent of all cancers in the white population (1). In more than $90 \%$ of cases tumor is localized on the face, lower lip, neck, ear lobes and dorsal hand side, but can also have specific localisation on tongue, penis or vulva. Surrounding skin usually shows features of acantholytic damage (7 ). Clinically, it is most commonly presented as shallow ulcers often with ceratotonic crust and elevation of indure environment. Tumor sometimes begins as hyperkeratotic or verrucous focal point. Progression is followed by tumor enlargement, and when it reaches a few centimeters ulcers or necrosis might occurre. During enlargement tumor is spreading in softt tissue, cartilage, and bone. It can metastasize to lymph nodes and distant tissues and organs $(7,8)$.

Squamous cell carcinoma can arise de novo or from precursors such as actinic keratosis. A deregulation of the cell cycle is one of the most common changes during carcinogenesis (9). Cell unwinding cycle is highly organized and highly regulated process that involves a number of checkpoints, and ensures complete and accurate replication of DNA and cell components before the division. Carcinogenesis is the consequence of accumulation of disorders in the structure and function of genes regulating mechanisms of cell proliferation, DNA repair and apoptosis in the molecule. These are the oncogenes, tumor suppressor genes and genes controlling programmed cell death $(10,11,12)$.

The most frequently mutated gene is TP53, located in humans on the short arm of chromosome 17 (17q13).
Its importance is reflected in itsrole in suppressing cell transformation and tumorigenesis, Therefore it belongs to the class of typical suppressor gene. TP53 is organized in 11 egzogenic sequences encoding the synthesis of the p53 protein which plays an important role in cell cycle regulation and preserving stability of the genome $(13,14)$. Considering scarce and controversial results about the expression of p53 in the skin tumors of the keratinocyte histogenesis, in this study we investigated the association of p53 expression with proliferative index and clinicopathological characteristics of keratinocyte skin cancers.

\section{MATERIALS AND METHODS}

\section{Patients and tissue samples}

The study included 78 patients who underwent excision me-melanoma skin cancer in the period from January $1^{\text {st }}$ to December $1^{\text {st }}, 2008$ in The centre for Plastic surgery in Clinical Center Kragujevac. Tissue samples were fixed in $10 \%$ buffered formalin solution, and after routine processing in autotehnicon, tumor tissues were embedded in paraffin and archived in The center of pathology in Kragujevac. Tissue sections $(3-4 \mu \mathrm{m})$ were stained with hematoxylin-eosin for histomorphological analysis of the tumor differentiation. For immunohistochemical staining we used paraffin embedded sections $(3-4 \mu \mathrm{m})$ and $A B C$ method with anti-cytokeratin, anti Ki67- and anti p53- antibodies.

The study included 33 squamous cell carcinoma, 30 actinic keratosis and 15 keratoacanthoma. Patient clinicopathologic parameters are shown in Table 1. The study protocol was approved by the local Ethics Committee.

\section{Immunohistochemistry}

Paraffin sections were heated at $55^{\circ} \mathrm{C}$ to melt the paraffin, deparaffinized in xylene for 5 min three times and them rehydrated in a series of $100 \%, 96 \%, 70 \%$ and $50 \%$ alcohol. Antigen retrieval was performed by microwave heating for 20 minutes in $10 \mathrm{mM}$ sodium citrate buffer (pH 6. 0). Endogenous peroxidase activity was blocked by $3 \% \mathrm{H}_{2} \mathrm{O}_{2}$ in methanol for $20 \mathrm{~min}$. Rabbit monoclonal Ki67 antibody (Abcam, Cambridge, UK; 1:100 dilution) and monoclonal mouse anti-human p53 (DAKO Denmark; 1:100 dilution) and monoclonal mouse anti-cytokeratin antibody (clone AE1/AE3; DAKO Glostrum, Denmark;1:200 dilution) were incubated at $+4^{0} \mathrm{C}$ overnight. Immunostaining was performed by the 
Table 1. Patient clinicopathological characteristics according to tumor histotypes

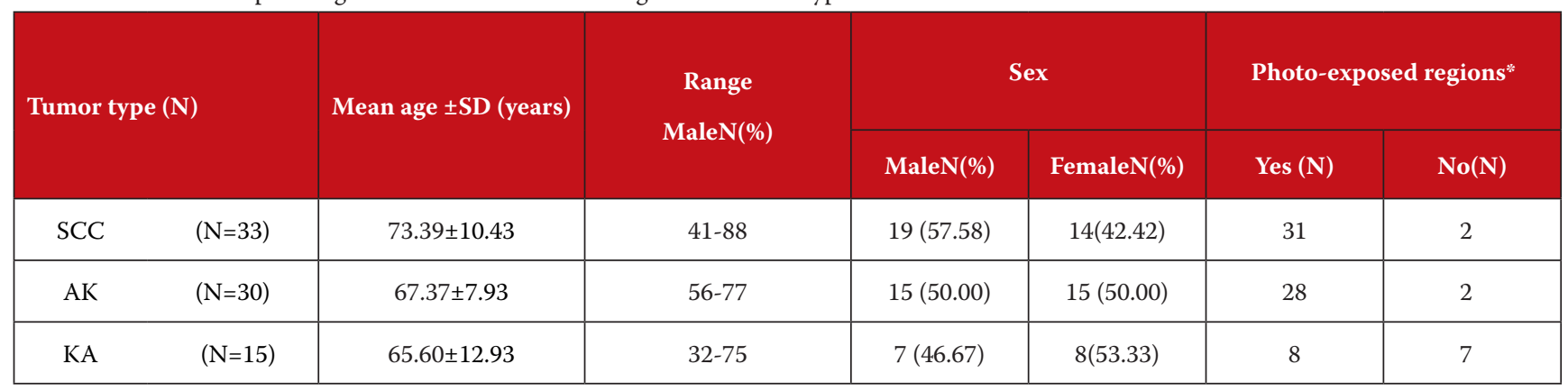

"Photo-exposed regions are: scalp, face (cheek, forehead, chin, temple, nose, ear), surfaces of upper limbs, chest and upper back

Table 2. Comparison between patient's age and type of keratinocyte tumor.

\begin{tabular}{|c|c|c|c|}
\hline Tumor type & SCC & KA & AK \\
\hline SCC & $/$ & $\mathrm{p}=0.006 *$ & $/$ \\
KA & $\mathrm{p}=0.006 *$ & $\mathrm{p}=0.002 *$ & $\mathrm{p}=0.718$ \\
AK & $\mathrm{p}=0.002 *$ & $\mathrm{p}=0.718$ & $/$ \\
\hline
\end{tabular}

* $p<0.05$ Mann-Whitney $U$ test

avidin-biotin peroxidase complex $(\mathrm{ABC})$ method (Vectastain ABC-Elite kit, Vector Laboratories, Burlingame, CA).

Staining was visualized with 3,3 diaminobenzidine tetrachloride $(\mathrm{DAB})$. The slides were counterstained with Mayer hematoxylin and mounted in Canada balsam. Negative controls were done by replacing the primary antibody with phosphate buffered solution (PBS). The slides were examined by conventional light microscopy.

\section{Quantification of immunohistochemical staining}

In evaluating the expression of Ki67 and p53, only stained nuclei were taken into account, while for the evaluation of Ki67-positive cells per $\mathrm{mm}^{2}$ by area the multipurpose test system M42 by Weibel was used. The objective micrometer (Reichert Wien $2 \mathrm{~mm} / 200$ ) was used to determine the measuring area of $0.016 \mathrm{~mm}^{2}$

For testing Ki67 and p53, positive cells $/ \mathrm{mm}^{2}$ were counted successively by 10 "hot spots". The absolute value of the density of positive cells in the "hot spot" was determined stereometrically (15). The arithmetic mean of the obtained values of the "hot spots" represented the final number of Ki67 and p53 positive cells per $\mathrm{mm}^{2}$ per case. The median was subsequently determined and the absolute values of the density of positive cells were divided into two groups: those with low expression level (value $\leq$ the median value) and those with high level of expression (values $>$ the median value). These values represented the proliferative activity (proIDX). $(1+2+$ low or high index). It is also referred to an absolute value of a p53 in relation to deviation from the median obtained index of p53 expression $(1+2+$ or low: high). Cytokertine expression was not evaluated since cytokeratine antibody was used as a differencial marker for keratinocyte tumors.

\section{Statistical analysis}

Data are presented as means \pm SDor as proportions. Results were analyzed using the Chi-sqare test or Fish- er's Exact test and, where appropriate, Mann-Whitney U test. Relationships between variables wereassessed using Spearman's Correlation test. Values of $\mathrm{p}<0.05$ were considered as statisticallysignificant. Statistical analyses were performed using SPSS 22. 0. for Windows software (SPSS, Inc. , Chicago, IL).

\section{RESULTS}

Total number of patients with keratinocyte skin tumors was 78, and the average age of subjects was 69, 58 (range 32-88). Squamous cell carcinoma (SCC) was found in 33 patients and the average age was 73.39 years. In the group with actinic keratoses (AK) 30 subjects were found, mean age 67, 37, while in the group with keratoacanthoma (KA) , 15 to 70 years of age, there were the following results: $S C C=3, A K=9, K A=4$. In the group of the patients from 71 to 80 years of age, distribution is: $S C C=20, A K=13, K A=5$, while in the age group from 81 to 90 years of age, distribution was the following $S C C=6, A K=1, K A=1$. In the group of patients with SCC , 57. 58\% of them were male and 42 . $42 \%$ female, in patients with AK 50\% were male and 50\% female. In patients with KA $46.67 \%$ of them were male and 53. 33\% female. There were no significant correlations between the type of keratinocyte tumor and gender of patients, but we have noticed that in the SCC group, male subjects have been more affected (Table 1).

A statistically significant relation is noticed among the patient age and the patient type tumor carcinoma. Average age of the patients with SCC is statistically significantly higher than average patient age with AK (Mann-Whitney $U$ test; $\mathrm{p}=0,002)$ and also from average patient age range with the KA (Mann-Whitney $U$ test; $\mathrm{p}=0,006)$. There was no difference in average age between the patients with $\mathrm{AK}$ and the patients with KA (Mann-Whitney $U$ test, $\mathrm{p}=0$. 718). (Table 2). 
Figure 1. Comparison between photo-exposed regions and different type of keratinocyte tumor.

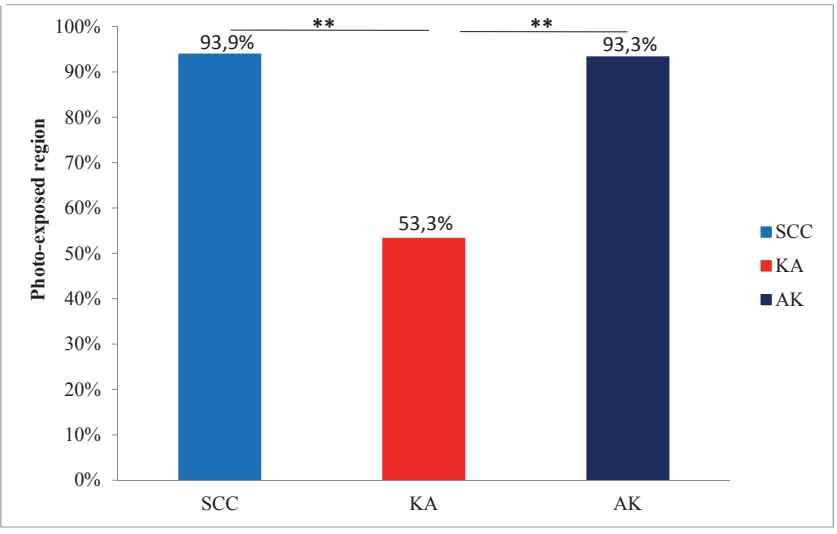

*** Chi-sqare test, $p=0.001$

Values are expressed like percent of patients with tumor localized on photo-exposed region.

There was a statistically significant difference in the prevalence of patients with different tumor localization. In SCC and AK groups, tumor localization was significantly more often on photoexposed region (Chi-sqare test $\mathrm{p}=0.000$ ), but there were no significant difference in the occurence of KA at photoexposed region and photo-non exposed (Chi-sqare test $r=0.549$ ). There is a significant difference in tumor occurrence in the region between photo-exposed SCC and KA (Chi-sqare test $\mathrm{r}=0.001$ ) and between the AK and KA (Chi-sqare test $\mathrm{p}=0.001)$. SCC is significantly more likely to occur in the photo exposed region (93. 9\% of cases) compared to KA (53. 3\% of the cases). AK was also significantly higher (93. 3\% cases) on photo-exposed region compared to KA (Chi-sqare test $r$ $=0.001)$. Between AK and SCC no significant differences in the incidence of the photo - exposed region was found. (Chi-sqare test $r=0.942$ ) (Fig. 1).

High proliferative index was found in $75.8 \%$ of cases in the SCC group, 6. 7\% in AK and 73. 3\% in the KA. Percentage of patients with high proliferative index was highest in SCC and KA groups, and also there were no difference between these two groups. High proliferative index was significantly less frequent in AK in relation to the SCC (Chi-sqare test $\mathrm{p}=0.000$ ) and KA (Chi-sqare test $\mathrm{p}=0$. $000)$. Low proliferation index was found in $24.2 \%$ of cases in SCC group, in 90. 0\% ofpatients in AK group and 26. 7\% of the patients in KA group. Low proliferative index prevalence was significantly higher in AKcompared to SCC (Chi-sqare test; $\mathrm{p}=0.000)$ and $\mathrm{KA}$ (Chi-sqare test $\mathrm{p}=0$. 000) (Table 3).

There is significant correlation between the proliferation index (Ki67 expression) and the tumor of localized photo exposed region. The biggest number of patients with SCC $(70 \%)$ has a high index of proliferation of the photo-exposed region, while in the AK patients there was significant corelation between the photo exposure region and the moderate proliferative index, that is encountered in $83 \%$ of cases (Spearman's corelation $\mathrm{p}=0.025$ ). (Fig. 2 ). The connection between the high index of proliferation and tumor localization was not observed in the KA group.

A statistically significant number of men have a high proliferative index in comparison to women in SCC (Chisqare test, $\mathrm{p}=0.015)$ (Table 4 ).

Expression of p53 is found in $87.8 \% \mathrm{SCC}$, in $83.3 \%$ $\mathrm{AK}$ and 13. 4\% KA. Hight index of p53 expression was found in $63.6 \%$ of the SCC, in $50.0 \%$ cases of AK, even in $6.7 \%$ cases of KA. There were no significant difference in high expression of p53 between SCC and AK. High levels

Figure 2. Correlation between photo-exposed regions and ekspression of Ki67 and p53 markers within different tumor type.

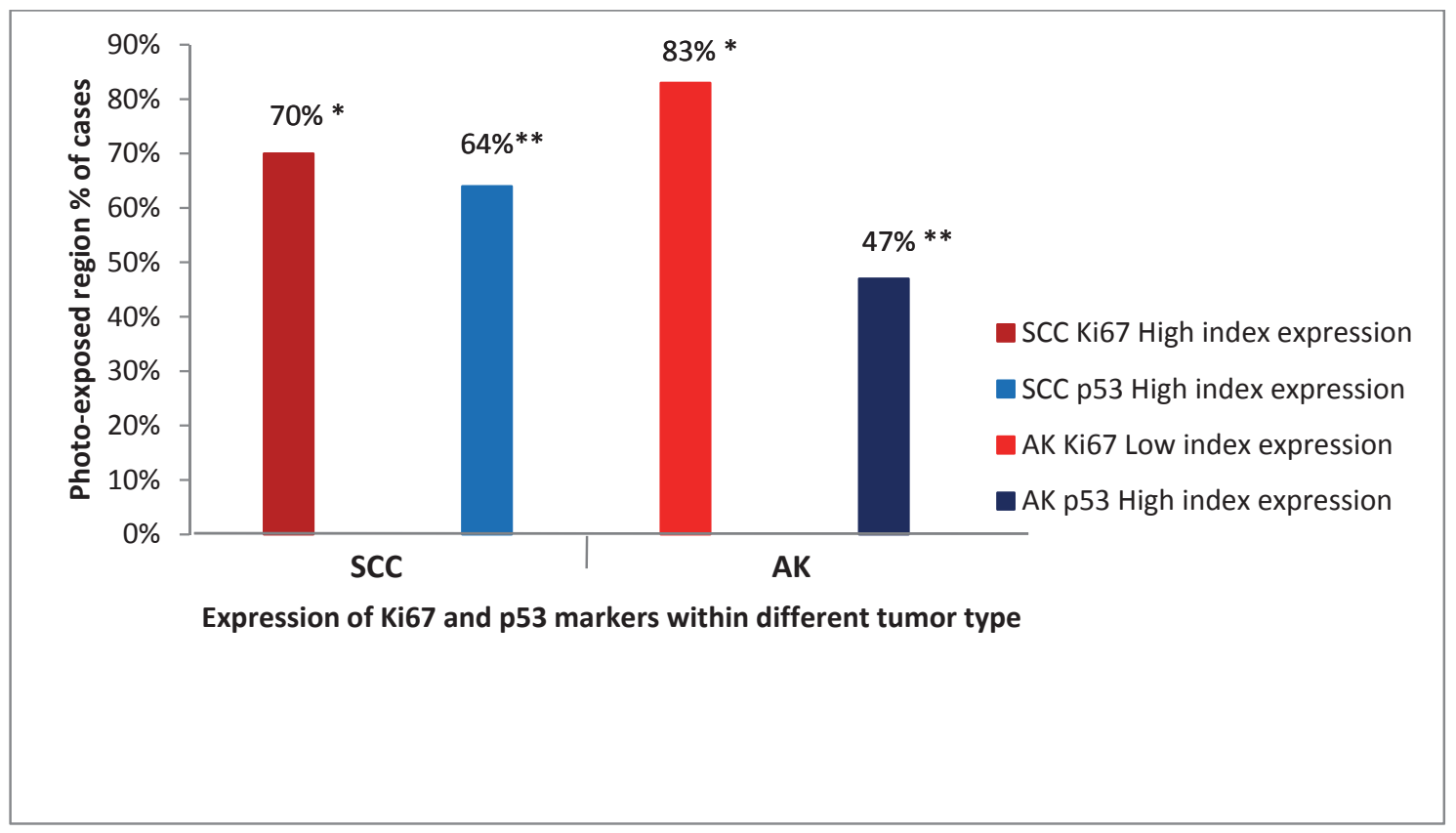

*Spearman's correlation, $p<0.05$

**Spearman's correlation, $p<0.001$ 
Table 3. Values of p53 and Ki67 expression within different tumor types and intergroup analysis

\begin{tabular}{|c|c|c|c|c|c|c|c|}
\hline & & \multicolumn{3}{|c|}{ Type of tumor } & \multicolumn{3}{|c|}{ Intergroup analysis } \\
\hline & & SCC & AK & KA & SCC-AK & SCC-KA & AK-KA \\
\hline \multicolumn{8}{|c|}{ Expression of p53 } \\
\hline \multirow{3}{*}{ 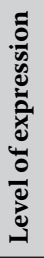 } & 0 & $4(12,1 \%)$ & $5(16,7 \%)$ & $13(86,7 \%)$ & - & $\mathrm{p}=0,000^{* * *}$ & $\mathrm{p}=0,000^{* * *}$ \\
\hline & $1+$ & $8(24,2 \%)$ & $10(33,3 \%)$ & $1(6,7 \%)$ & - & $\mathrm{p}=0,000^{* * *}$ & $\mathrm{p}=0,003^{*}$ \\
\hline & $2+$ & $21(63,6 \%)$ & $15(50 \%)$ & $1(6,7 \%)$ & - & $\mathrm{p}=0,000^{* * *}$ & $\mathrm{p}=0,000^{* * *}$ \\
\hline \multicolumn{8}{|c|}{ Expression of Ki67 } \\
\hline \multirow{3}{*}{ 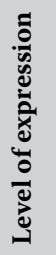 } & 0 & $0(0,0 \%)$ & $1(3,3 \%)$ & $0(0,0 \%)$ & - & - & - \\
\hline & $1+$ & $8(24,2 \%)$ & $27(90,0 \%)$ & $4(26,7 \%)$ & $\mathrm{p}=0,000^{* * *}$ & - & $\mathrm{p}=0,000^{* * *}$ \\
\hline & $2+$ & $25(75,8 \%)$ & $2(6,7 \%)$ & $11(73,3 \%)$ & $\mathrm{p}=0,000^{* * *}$ & - & $\mathrm{p}=0,000^{* * *}$ \\
\hline
\end{tabular}

0: absent expression, $1+$ : low level expression, 2+: high level expression

*Chi-sqare test, $p<0.05$

${ }^{* *}$ Chi-sqare test, $p<0.001$

of p53 expression were significantly more prevalent in AK and SCC compared to KA. (Chi-sqare test; $\mathrm{p}=0.000)$. Low level of expression was found in 24. 2\% SCC, in 33. $3 \% \mathrm{AK}$ and 6. 7\% KA. The low level of expression is significantly more frequent in SCC compared to KA (Chi-sqare test, $\mathrm{p}=0.000$ ) and significantly more frequent in AK compared to KA (Chi-sqare test $\mathrm{p}=0.003)$. The absence of expression of p53 was found in 12. 1\% SCC, 16. 7\%AK and $86.7 \%$ KA (Table 3 ).

There is a correlation between p53 expression and tumor localization. We demonstrated a positive correlation between p53 expression and photo exposure of tumor regionin SCC and AK. Significantly more patients with SCC $64 \%$ and $\mathrm{AK} 47 \%$ has a high index of p53 expression on

Table 4. Expression of p53 and Ki67 in SCC, AK and KA depending on the gender.

\begin{tabular}{|c|c|c|c|c|c|c|c|c|c|c|}
\hline \multicolumn{2}{|c|}{$\begin{array}{c}\text { Ki } 67 \text { and p53 } \\
\text { expression }\end{array}$} & \multicolumn{6}{|c|}{ Type of tumor } & \multicolumn{3}{|c|}{$\begin{array}{c}\text { Analysis according to the type of } \\
\text { tumor }\end{array}$} \\
\hline & & \multicolumn{2}{|c|}{$\mathrm{SCC}$} & \multicolumn{2}{|c|}{ AK } & \multicolumn{2}{|c|}{ KA } & \multirow{2}{*}{$\begin{array}{l}\text { SCC } \\
\text { M-F }\end{array}$} & \multirow{2}{*}{$\begin{array}{l}\text { AK } \\
\text { M-F }\end{array}$} & \multirow{2}{*}{$\begin{array}{l}\text { KA } \\
\text { M-F }\end{array}$} \\
\hline \multicolumn{2}{|c|}{ Gender } & $\mathbf{M}$ & $\mathbf{F}$ & $\mathbf{M}$ & $\mathbf{F}$ & $\mathbf{M}$ & $\mathbf{F}$ & & & \\
\hline & \multicolumn{10}{|c|}{ Ki67 expression } \\
\hline \multirow{3}{*}{ 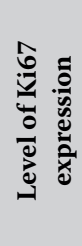 } & $\mathbf{0}$ & $\begin{array}{c}0 \\
(0 \%)\end{array}$ & $\begin{array}{c}0 \\
(0 \%)\end{array}$ & $\begin{array}{c}1 \\
(3,3 \%)\end{array}$ & $\begin{array}{c}0 \\
(0 \%)\end{array}$ & $\begin{array}{c}0 \\
(0 \%)\end{array}$ & $\begin{array}{c}0 \\
(0 \%)\end{array}$ & - & - & - \\
\hline & 1 & $\begin{array}{c}3 \\
(9,1 \%)\end{array}$ & $\begin{array}{c}5 \\
(15,2 \%)\end{array}$ & $\begin{array}{c}12 \\
(40 \%)\end{array}$ & $\begin{array}{c}15 \\
(50 \%)\end{array}$ & $\begin{array}{c}2 \\
(13,3 \%)\end{array}$ & $\begin{array}{c}2 \\
(13,3 \%)\end{array}$ & - & - & - \\
\hline & 2 & $\begin{array}{c}16 \\
(48,5 \%)\end{array}$ & $\begin{array}{c}9 \\
(27,3 \%)\end{array}$ & $\begin{array}{c}2 \\
(6,7 \%)\end{array}$ & $\begin{array}{c}0 \\
(0 \%)\end{array}$ & $\begin{array}{c}5 \\
(33,3 \%)\end{array}$ & $\begin{array}{c}6 \\
(40 \%)\end{array}$ & $\mathrm{p}=0,015$ & - & - \\
\hline & \multicolumn{10}{|c|}{ p53 expression } \\
\hline \multirow{3}{*}{ 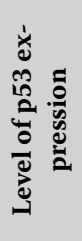 } & $\mathbf{0}$ & $\begin{array}{c}2 \\
(6,1 \%)\end{array}$ & $\begin{array}{c}2 \\
(6,1 \%)\end{array}$ & $\begin{array}{c}2 \\
(6,7 \%)\end{array}$ & $\begin{array}{c}3 \\
(10 \%)\end{array}$ & $\begin{array}{c}5 \\
(33,3 \%)\end{array}$ & $\begin{array}{c}8 \\
(53,3 \%)\end{array}$ & - & - & $\mathrm{p}=0,031^{*}$ \\
\hline & 1 & $\begin{array}{c}6 \\
(18,2 \%)\end{array}$ & $\begin{array}{c}2 \\
(6,1 \%)\end{array}$ & $\begin{array}{c}6 \\
(20 \%)\end{array}$ & $\begin{array}{c}4 \\
(13,3 \%)\end{array}$ & $\begin{array}{c}1 \\
(6,7 \%)\end{array}$ & $\begin{array}{c}0 \\
(0 \%)\end{array}$ & $\mathrm{p}=0,014^{*}$ & - & - \\
\hline & 2 & $11(33,3 \%)$ & $\begin{array}{c}10 \\
(30,3 \%)\end{array}$ & $\begin{array}{c}7 \\
(23,3 \%)\end{array}$ & $\begin{array}{c}8 \\
(26,7 \%)\end{array}$ & $\begin{array}{c}1 \\
(6,7 \%)\end{array}$ & $\begin{array}{c}0 \\
(0 \%)\end{array}$ & - & - & - \\
\hline
\end{tabular}

M-males, F-females;

*Chi-sqare test, $\mathrm{p}<0.05$ 
Table 5. Expresion of p53 by age, within different keratinocyte tumor.

\begin{tabular}{|c|c|c|c|c|c|c|c|c|c|c|c|c|c|}
\hline \multirow{2}{*}{\multicolumn{2}{|c|}{$\begin{array}{c}\text { Expression } \\
\text { of p53 }\end{array}$}} & \multicolumn{12}{|c|}{ Type of tumor } \\
\hline & & \multicolumn{3}{|c|}{ SCC } & \multicolumn{4}{|c|}{ AK } & \multicolumn{5}{|c|}{$\mathbf{K A}$} \\
\hline \multicolumn{2}{|c|}{ Age } & $<=60$ & $61-70$ & $71-80$ & $81-90$ & $<=60$ & $61-70$ & $71-80$ & $81-90$ & $<=60$ & $61-70$ & $71-80$ & $81-90$ \\
\hline \multirow{3}{*}{ 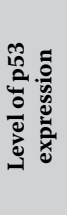 } & 0 & $\begin{array}{c}0 \\
(0 \%) \\
\end{array}$ & $\begin{array}{c}1 \\
(33 \%) \\
\end{array}$ & $\begin{array}{c}3 \\
(15 \%)\end{array}$ & $\begin{array}{c}0 \\
(0 \%)\end{array}$ & $\begin{array}{c}0 \\
(0 \%)\end{array}$ & $\begin{array}{c}2 \\
(22 \%)\end{array}$ & $\begin{array}{c}3 \\
(23 \%)\end{array}$ & $\begin{array}{c}0 \\
(0 \%)\end{array}$ & $\begin{array}{c}4 \\
(80 \%)\end{array}$ & $\begin{array}{c}4 \\
(100 \%)\end{array}$ & $\begin{array}{c}4 \\
(80 \%)\end{array}$ & $\begin{array}{c}1 \\
(100 \%)\end{array}$ \\
\hline & 1 & $\begin{array}{c}0 \\
(0 \%)\end{array}$ & $\begin{array}{c}2 \\
(67 \%)\end{array}$ & $\begin{array}{c}4 \\
(20 \%)\end{array}$ & $\begin{array}{c}2 \\
(33 \%)\end{array}$ & $\begin{array}{c}3 \\
(43 \%)\end{array}$ & $\begin{array}{c}4 \\
(44 \%)\end{array}$ & $\begin{array}{c}3 \\
(23 \%)\end{array}$ & $\begin{array}{c}0 \\
(0 \%)\end{array}$ & $\begin{array}{c}1 \\
(20 \%)\end{array}$ & $\begin{array}{c}0 \\
(0 \%)\end{array}$ & $\begin{array}{c}0 \\
(0 \%)\end{array}$ & $\begin{array}{c}0 \\
(0 \%)\end{array}$ \\
\hline & 2 & $4(100 \%)$ & $\begin{array}{c}0 \\
(0 \%)\end{array}$ & $\begin{array}{c}13 \\
(65 \%)\end{array}$ & $\begin{array}{c}4 \\
(67 \%)\end{array}$ & $\begin{array}{c}4 \\
(57 \%)\end{array}$ & $\begin{array}{c}3 \\
(33 \%)\end{array}$ & $\begin{array}{c}7 \\
(54 \%)\end{array}$ & $\begin{array}{c}1 \\
(100 \%)\end{array}$ & $\begin{array}{c}0 \\
(0 \%)\end{array}$ & $\begin{array}{c}0 \\
(0 \%)\end{array}$ & $\begin{array}{c}1 \\
(20 \%)\end{array}$ & $\begin{array}{c}0 \\
(0 \%)\end{array}$ \\
\hline \multicolumn{14}{|c|}{ Intergroup analysis } \\
\hline \multirow{2}{*}{\multicolumn{2}{|c|}{ Age }} & \multicolumn{3}{|c|}{$<=60$} & \multicolumn{3}{|c|}{$61-70$} & \multicolumn{3}{|c|}{$71-80$} & \multicolumn{3}{|c|}{$81-90$} \\
\hline & & SCC-AK & SCC-KA & AK-KA & SCC-AK & SCC-KA & AK-KA & SCC-AK & SCC-KA & AK-KA & SCC-AK & SCC-KA & AK-KA \\
\hline \multirow{3}{*}{ 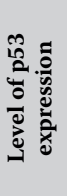 } & 0 & - & $\mathrm{p}=0,000^{* * *}$ & $\mathrm{p}=0,000^{* * *}$ & - & $\mathrm{p}=0,001^{* *}$ & $\mathrm{p}=0,05^{*}$ & - & - & - & - & $\mathrm{p}=0,000^{* * *}$ & $\mathrm{p}=0,000^{* * *}$ \\
\hline & 1 & $\mathrm{p}=0,042^{*}$ & - & $\mathrm{p}=0,009^{* *}$ & $\mathrm{p}=0,05^{*}$ & $\mathrm{p}=0,001^{* * *}$ & $\mathrm{p}=0,000^{* *}$ & - & $\mathrm{p}=0,000^{* * *}$ & $\mathrm{p}=0,014^{*}$ & $\mathrm{p}=0,000^{* * *}$ & $\mathrm{p}=0,000^{* * *}$ & - \\
\hline & 2 & - & $\mathrm{p}=0,000^{* * *}$ & $\mathrm{p}=0,000^{* * *}$ & $\mathrm{p}=0,000^{* * *}$ & - & $\mathrm{p}=0,000^{* * *}$ & $\mathrm{p}=0,027^{*}$ & $\mathrm{p}=0,000^{* * *}$ & $\mathrm{p}=0,001^{* * *}$ & $\mathrm{p}=0,000^{* * *}$ & $\mathrm{p}=0,000^{* * *}$ & $\mathrm{p}=0,000^{* *}$ \\
\hline
\end{tabular}

* Chi-sqare test, $p \leq 0.05$

** Chi-sqare test, $p<0.001$

photo exposed tumor region (Spearman's correlation, $\mathrm{p}=$ 0. 000). (Figure 2). Correlation between the expression of this marker and localization was not observed in the KA. Significantly more women have absence of p53 expression in KA compared to men (Chi-sqaretest, $\mathrm{p}=0.031$ ), while a statistically significant number of men have low index of p53 expression compared to women in SCC (Chi-sqare test, $\mathrm{p}=0.014)($ Table 4$)$.

In patients younger than 60 years of age, frequency of high index of $\mathrm{p} 53$ expression was significantly higher in the SCC compared to KA (Chi-sqare test, $\mathrm{p}=0$. 000). In this population there were no statistically significant difference in the prevalence of high index of p53 expression between the SCC and the AK, but the high index of p53 expression was significantly more frequent in the AK compared to KA (Chi-sqare test, $\mathrm{p}=0.000$ ). The low index of $\mathrm{p} 53$ expression was significantly less frequent in SCC compared to $\mathrm{AK}$, and also significantly more frequent in the AK compared to KA. In this group of patients the absence of p53 expression was significantly lower in the SCC and the AK compared to KA (Table 5).

In the group of respondents aged 61 to 70 years, a high index of p53expression was significantly more common in AK compared to SCC and KA, and statistical significance was not found between the SCC and KA. Low index of p53 expression were significantly more prevalent in the AK as compared to SCC and KA. Significantly more patients with SCC have a low index of p53 expression as compared
A

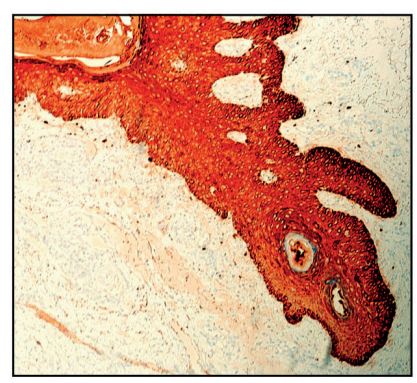

B

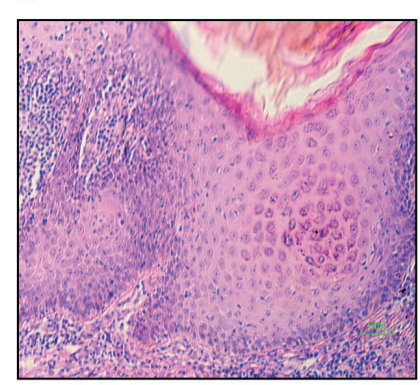

C

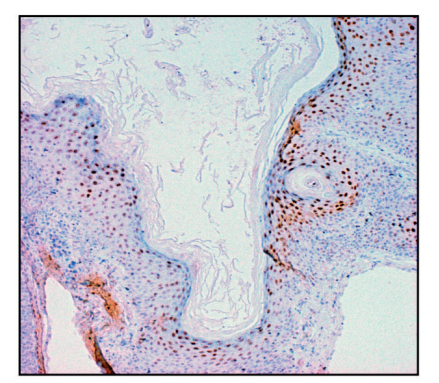

Figure 3: Keratoacathoma

A) Diffuse high expression of cytokeratin in whole epiderm with pronounced focal intensity in basal keratinocytes (AE1/AE3; magnification X 200),

B) Bottom of keratin plug, hiperplasion of granulose layer with increased mitotic activity (AB-PAS, magnification X 400),

C) Diffuse proliferative activity of epidermal keratinocites in the surroundings of keratin plug (Ki67, magnification X 200) 
to KA. The absence of p53 expression was significantly lower in the SCC and the AK in relation to keratoacanthoma. (Table 5).

In subjects 71 to 80 years of high index of p53 expression were significantly more frequent in SCC compared to $\mathrm{AK}$ and $\mathrm{KA}$, as well as $\mathrm{AK}$ in relation to KA. Low index of expression of this protein is significantly more common in SCC and the AK compared to KA. , Between AK and SCC there were no statistically significant differences in the low expression of $\mathrm{p} 53$. Also, in this population there was no significant difference in the absence of $\mathrm{p} 53$ expression between the different tumor types (Table 5).

In the group of subjects aged 81 to 90 years, high index of p53 expression was significantly more frequent in SCC compared to AK and KA, as well as in AK compared to KA. The low index of p53expression was significantly more frequentin SCC compared to AK and KA, while between the AK and KA there were no significant difference in the low p53 expression. The absence of p53 expression was significantly lower in patients with SCC and the AK compared to KA, while between the AK and the SCCno difference was found. (Table 5).

In patients younger than 60 years of age high index of expression of Ki67 was significantly more frequent in SCC and KA compared to AK, and statistically significant difference was not found between SCC and KA. The low index of expression of the p53 is significantly less frequent in SCCthan in AK, whereas statistical significance was not found between the SCC and KA. In this group of patients there is no statistical significance in the absence of the expression of Ki67 and tumor types.

In the group of respondents aged 61 to 70 years, a high index of expression of Ki67 was significantly more frequent in SCC and KA relative to AK, and statistical significance was not found between the SCC and KA. Low index of expression of Ki67 were significantly more frequent in AK in relation to the SCC and KA, while significantly more subjects with KA has a low index of expression of Ki67 in comparison to the SCC. The absence of expression of Ki67 was significantly less for SCC and KA in comparison to the $\mathrm{AC}$, while between the SCC and KA there is no statistical significance.

In subjects aged from 71 to 80 years, high index of Ki67expression was significantly more frequent in SCC and KA in comparison to the AK, and between SCC and KA no difference was found. Low expressionindex of this protein is significantly more common in AK compared to SCC and KA, while between SCC and KA no difference was found. In this population subjects there was no significant difference in the absence of the Ki67expression between different tumor types.

In the group of subjects aged from 81 to 90 years, high index of expression of $\mathrm{Ki} 67$ was significantly more frequent in SCC compared to AK and KA, as well as the KA with respect to AK. The low index of expression of Ki67 is significantly more frequent in AK compared to SCC and KA, as in SCC compared to KA. In the study group, there were no
A

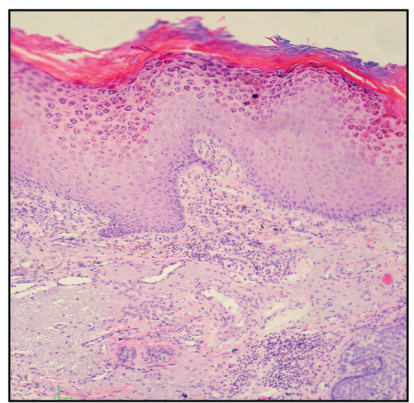

B

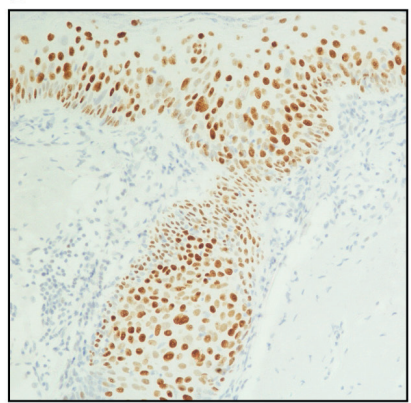

Figure 4: Solar keratosis

A) Acantosis and hiperplasion of granulose layer (HE, magnification $\mathrm{X}$ 200)

B) Diffuse nuclear p53 expression along whole epidermis (p53, magnification X 200)C) Diffuse p53 expression in moderate differentiated squamocelular carcinoma (p53, magnification X 200)

D) Moderate proliferative activity with nuclear and cellular atypia in moderate differentiated squamocelular carcinoma (Ki67, magnification X 200)
A

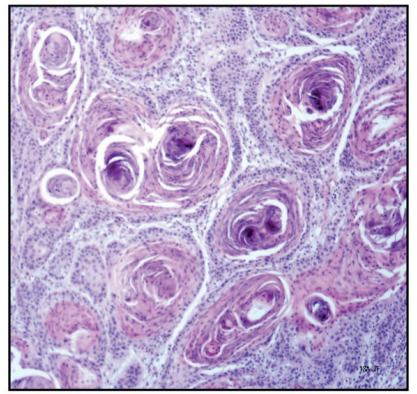

C

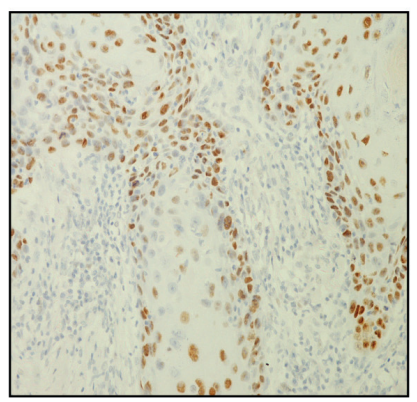

B

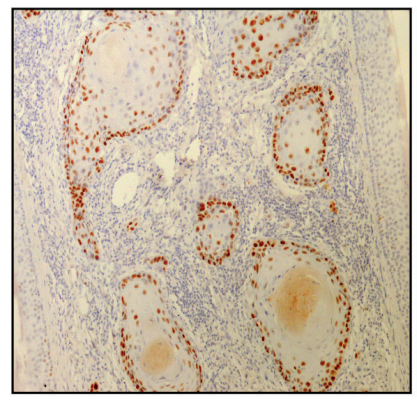

$\mathrm{D}$

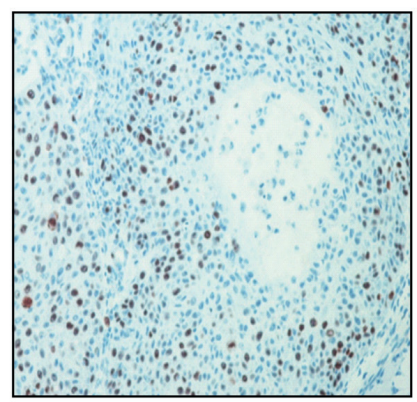

Figure 5: Squamocelular carcinoma

A) Well diferented type with epithelial cells distributed in bulbar shape and "cancer pearls" in the center (HE, magnification X 200)

B) Intensive nuclear p53 expression predominantly on periphery of "tumor islands", in well diferrentiated squamocelular carcinoma (p53, magnification X 200)

significant difference in the absence of the Ki67expression in various tumor types.

Correlation analyzes of Ki67 and p53 expression in a keratinocyte tumors demonstrated a significant positive correlation between these two markers in the $\mathrm{SCC}(\mathrm{p}<0.05 \mathrm{p}=0.028$; Spearman's rho 0, 377). Correlation between the expression of Ki67 and p53 was not found in the AK and KA. 


\section{DISCUSSION}

The development of squamous cell carcinoma is a multistage process in which a number of molecular disorders occurs that lead to neoplastic transformation of keratinocytes. The key events in keratinocyte carcinogenesis include activation of protooncogenes and inactivation of tumor suppressor genes. A classic example of a suppressor gene is a gene TP53 which encodes a multifunctional protein $\mathrm{p} 53$. Somatic mutations of this gene are the most frequent gene mutations in human cancers, and has been estimated to occur in 50-90\% of malignant tumors, depending on the type and stage of the tumor $(16,17)$. From 1989. till today, in over 2700 published papers numerous evidences for more than 35000 TP53 mutations were described $(18,19)$. The mutated gene is changing the structure and function of the encoded protein, initiate the process of oncogenesis and lead to accumulation of p53 in tumor tissue $(20,21)$.

As expected, reports on the expression of p53 in keratinocyte tumors are quite heterogeneous. In our study, the expression of $\mathrm{p} 53$ was present in $87.8 \%$ of SCC, $83.3 \%$ of AK and 13. 4\% of KA patients, which is consistent with previous reports of Karagece et al and Park et al $(22,23)$. However, Dornelas et al have recently demonstrated the expression of p53 in all cases (100\%) tested in the SCC and the AK (24), while in the study of Khodaeiani et al, p53 was detected in $50.20 \%$ of SCC, and was absent in KA patients (25). Almost more than two decades ago, Lee et al. demonstrated that p53 expression was present even at the $78.8 \%$ of the tested KA and 75. 5\% of the SCC (26). In our study, we showed significantly higher frequency of high index of p53 expression in the SCC and the AK in relation to KA. These findings are in favor of concept that the common factor, such as actinic damage may be responsible for both lesions (SCC and the AK). In the other hand, majority of SCC is a p53 pozitive, regardless of whether they are localized on the photo exposed parts of the body or not, which indicates that, in addition to actinic damage, in the keratinocyte carcinogenesis other pathogenetic mechanisms can also be involved $(26,27,28)$

A statistically significant majority of our patients with SCC and the AK has a high index of p53 expression in tumors that are localized to the photo exposed region. $\mathrm{Nu}$ merous reports confirmed that keratinocyte tumors occurring as a result of exposure to ultraviolet radiation $(3,29$, $30,31)$. About $90 \%$ of UV radiation consists of UVA rays (320-380 $\mathrm{nm}$ in the solar spectrum), while the UVB rays (290-320 $\mathrm{nm}$ in the solar spectrum), make up about 1-10\% of the UV radiation. However, when absorbed by the keratinocyte DNA, UVB rays cause genotoxicity and mutations of the p53 gene $(2429,32)$. P53 induction is detected in the skin after 30 minutes after exposure to UVB radiation (33). The presence of p53 expression in a high percentage (83. $3 \%$ ) in the AK, in this study, confirms the observation that the mutation of the p53 gene is early event in keratinocyte carcinogenesis (32) .
P53 belongs to transcriptional factors and when enabled, allows the expression of several genes, one of which is $\mathrm{p} 21$, which belongs to the group of inhibitors of cyclin dependent kinases (CKIs), and arrest cells in the G1 phase of the cell cycle. Protein p53 can halt the progression of the cycle in the G2 phase and even during mitosis. In the case of irreversible damage to the DNA p53 induces the activation of apoptosis (31). Mutational events form that inactivate p53 is specific for each individual tumor. It has been noted that the loss of p53 function, in patients with SCC, is most frequently associated with mutation of cytosine and thymidine dimer (so called "tandem mutation") $(32,34)$.

The absence of p53 expression in tumor islands with pronounced keratinization, in well-differentiated SCC, and high index of p53 expression in poorly differentiated $\mathrm{SCC}$, suggests that the presence of p53 is indicator of the immaturity of the tumor cells and the proliferative capacity of tumors. In accordance with this interpretation is the observation that high-grade tumors have a higher level of expression of p53 (35).

In this study, there were no significant differences in the prevalence of high index of expression of p53 between the SCC and the AK, and at the same time, a positive correlation between the expression of $\mathrm{p} 53$ in these tumors and localization in photoexposed region was shown. It was also observed that between SCC and AK there is no significant difference in the incidence of the photoexposed region. These results were supported by the concept that the exposure to UV light is the main cause of p53 mutations. This is supported with the report of Batinac et al, in which the expression of the p53 was detected in $39.0 \%$ of cases in the normal epidermis exposed to UV radiation (35). There are suggestions in the literature that the expression of p53 is correlated with poor prognosis and / or a lack of response on therapy $(25,36)$.

Most keratinocyte tumors with high proliferation index were in the group with SCC and KA, which is to be expected since these two histologically similar tumors have a pattern of growth, including cytologic atypia and infiltration (37). Despite the fact that between the two types of tumor there were no differences in the prevalence of high proliferation index, however, the correlation with high proliferation index is observed only in photoexposed region in SCC. High proliferative index was significantly lower in AK than in SCC and KA, but in a high percentage (83\%) of AK patients there is strong correlation between a moderate proliferation index and tumor localization in photoexposed region. UV radiation, not only damages the DNA of keratinocytes, but also reduces the immune response of the skin and reduces the body's ability to carry out repair adverse change $(37,38)$.

P53 mutants indicates that the damage is caused by UV light $(24,39)$, and the cells which are succumbed to DNA damaging continue to grow and to divide. Typically, the exhibit keratinization disorder is clinically manifested as an area of rough skin. While the changes are localized above the basal membrane, lesions represent a squamous 
cell carcinoma "in situ". At some point, malignant cells can penetrate into the dermis, to give the invasive squamous cell carcinoma. Period of evolution is about 10-20 years and probably about $8-20 \%$ of actinic keratoses develop into squamous cell carcinoma. It is believed that patients with actinic keratoses are about 200 times more likely to develop squamous cell carcinoma (1). Changes ascending and infiltration, multiple ulcerations and inflammation of the surrounding are clinical signs suggestive of malignancy (40).

Sporadically there are suggestions that solar keratosis should be considered as squamous cell carcinoma "de novo", and not as a pre-cancerous lesion that evolves into squamous cell carcinoma. $(41,8)$, yet in the literature there is consistent view that the disease is classified into the precursor of squamous cell carcinoma $(1,2,37)$. Numerous intraepidermal proliferative disorders can be precursors of squamous cell carcinoma but actinic keratoses are characterized by a dysplastic epithelium usually on body parts exposed to the sun $(19,20)$.

High proliferative index in KA, observed in our study, which is no different from the index of proliferation in the SCC, was also reported by other authors, but unlike many other authors $(1,35,37,39)$ we haven't observed association of KA with exposure to ultraviolet radiation. In addition, in this study the expression of p53 in KA did not positively correlated with tumor localization on photoexposed region, such as in the case with the SCC and AK. This points to a complex phenotype and heterogeneous etiology of KA. Speaking in favor of that, also goes a recent findings in the statement that $\mathrm{KA}$ is a separate entity caused by alteration of the TGF $\beta$ signaling pathway (42).

In line with other reports $(22,32)$ are our findings that there is significant association between the age of patients and the type of tumor keratinocyte, respectively our patients with SCC are significantly older than patients AK and KA. We also observed significant correlation between age of patients and p53 expression. Specifically in subjects younger than 60 years of age, significantly more common was high index of p53 expression in SCC then in other keratinocyte tumors, but with age, expression of p53 increases in the AK which could explain the prolonged exposure to UV radiation. Similar observations have been published by Turkish authors who have furthermore pointed out a strong correlation with the p53 expression to the tumor size in AK (22). Our correlation analysis identified a significant association of the proliferation index and the expression of p53 only in the SCC, which has also been observed by other authors $(43,44)$. In all age groups, in this study, a high proliferative index was significantly more frequent in SCC and KA than in AK.

Between the type of tumor and gender we did not find a significant association but we have noted that the SCC is slightly more frequent in male patients, and accordingly, there are reports according to which SCC occurs in males 2: 1 to 3. $3: 1$ ratio in relation to females $(45,46)$

\section{CONCLUSION}

Proliferation index and the index of the expression of p53 are useful for the differentiation of precursor lesions from keratinocyte skin carcinoma. Overexpression of p53 is associated with the process of aging and significantly correlated with exposure to UV radiation, especially in the SCC and AK.

Finally, high expression of Ki67 is a good indicator of proliferative activity, and high expression of p53 in AK and SCC supports additional pathogenetic significance of this oncoprotein in carcinogenesis of the skin.

\section{ACKNOWLEDGEMENT}

This work was supported by the Junior Project 16/10, Faculty of Medical Sciences, University of Kragujevac, Serbia.

\section{DISCLOSURE}

The authors declare they have no competing interests or other interests that might be perceived to influence the results and discussion reported in this paper.

\section{REFERENCES}

1. Wedon D, Marks R, Kao GF, Harwood CA: Keratinocytic tumours. In: World Health Organisation Classification of Tumours (ed): Pathology and genetics of skin Tumours. IARC Press, Lyon, 2006; 10-48.

2. Bumpous J. Metastatic cutaneous squamous cell carcinoma to the parotid and cervical lymph nodes: treatment and outcomes. Curr Opin Otolaryngol Head Neck Surg. 2009, 17(2):122-5. )

3. De Grujil FR, Norval M, Cullen AP, Slaper H, Kripke $M L$, vander Leun JC: Health effects from stratosphericozone depletion and interactions with climate change. Photochem Photobiol Sci, 2003, 2:16-28. ;

4. Reichrath J, Rass K. Ultraviolet damage, DNA repair and vitamin $\mathrm{D}$ in nonmelanoma skin cancer and in malignant melanoma: an update Adv Exp Med Biol. 2014;810:208-33.

5. Sadamori N, Mine M, Honda T: Incidence of skin cancer among Nagasaki atomic bomb survivors. J Rad Res Tokyo;1991, 2:217-225)

6. Marehbian J, Colt JS, Baris D, Stewart P, Stukel TA, Spencer SK, Karagas MR. Occupation and keratinocyte cancer risk: a population-based case-control study. Cancer Causes Control. 2007, 18(8):895-908

7. Lau P, Li Chang HH, Gomez JA, Erdeljan P, Srigley JR, Izawa JI. A rare case of carcinoma cuniculatum of the penis in a 55-year-old. Can Urol Assoc J. 2010;4(5):E129-32. 
8. Ackerman AB: The major types of squamous cell carcinoma. Dermatovenerology, practica \& conceptual, 2001, 5:250-252.

9. Emmert S, Schön MP, Haenssle HA. Molecular biology of basal and squamous cell carcinomas. Adv Exp Med Biol. 2014;810:234-52.

10. Kubo Y, Murao K, Matsumoto K, Arase S: Molecular carcinogenesis of squamous cell carcinomas of the skin. J Med Invest; 2002, 49:111-117.

11. Lazarov M, Kubo Y, Cai T, Dajee M, Tarutani M, Lin Q, Fang M, Tao S, Green CL, Khavari PA. CDK4 coexpression with Ras generates malignant human epidermal tumorigenesis. Nat Med. 2002;8(10):1105-1114

12. Tomas D: Apoptosis, UV-radiation, precancerosis and skin tumors. . Acta Med Croatica. 2009;63 Suppl 2:53-8.

13. Isobe M, Emanuel BS, Givol D, Oren M, Croce CM. Localization of gene for human p53 tumour antigen to band 17p13. Nature 1986; 320:84-5.

14. Petitjean A, Achatz MI, Borresen-Dale AL, Hainaut P, Olivier M. TP53 mutations in human cancers: functional selection and impact on cancer prognosis and outcomes. Oncogene 2007; 26:2157-65.

15. Mouton PR: Unbiased Stereology: A Concise Guide. Baltimore John Hopkins University Press, 2011, first edition, pp1-171

16. Stratigos AJ, Kapranos N, Petrakou E, Anastasiadou A, Pagouni A, Christofidou E, Petridis A, Papadopoulos O, Kokka E, Antoniou C, Georgala S, Katsambas AD. Immunophenotypic analysis of the p53 gene in non-melanoma skin cancer and correlation with apoptosis and cell proliferation. J Eur Acad Dermatol Venereol, 2005, 19(2):180-186.

17. Marinescu A, Stepan AE, Mărgăritescu C, Marinescu AM, Zăvoi RE, Simionescu CE, Niculescu M. P53, p16 and Ki67 immunoexpression in cutaneous squamous cell carcinoma and its precursor lesions. Rom J Morphol Embryol. 2016;57(2 Suppl):691-696.

18. Soussi T, Asselain B, Hamroun D, Kato S, Ishioka C, Claustres M, Béroud C. Meta-analysis of the p53 mutation database for mutant p53 biological activity reveals a methodologic bias in mutation detection. Clin Cancer Res. 2006 ;12(1):62-9.

19. Edlund K, Larsson O, Ameur A, Bunikis I, Gyllensten U, Leroy B, Sundström M, Micke P, Botling J, Soussi T. Data-driven unbiased curation of the TP53 tumor suppressor gene mutation database and validation by ultradeep sequencing of human tumors. Proc Natl Acad Sci U S A. $2012 ; 109(24): 9551-6$.

20. Naruke Y, Nakashima M, Suzuki K, Kondo H, Hayashi T, Soda M, Sekine I. Genomic instability in the epidermis induced by atomic bomb (A-bomb) radiation: a long-lasting health effect in A-bomb survivors. Cancer. 2009;115(16):3782-90

21. Queille S, Luron L, Spatz A, Avril MF, Ribrag V, Duvillard P, Hiesse C, Sarasin A, Armand JP, Daya-Grosjean L. Analysis of skin cancer risk factors in immunosuppressed renal transplant patients shows high levels of UV-specific tandem CC to TT mutations of the p53 gene. Carcinogenesis. 2007 Mar;28(3): 724-31.
22. Karagece Yalçin U, Seçkın S. The expression of p53 and COX-2 in basal cell carcinoma, squamous cell carcinoma and actinic keratosis cases. Turk Patoloji Derg. 2012;28(2):119-27

23. Park H-R, Min SK, Cho HD, Kim KH, Shin HS, Park YE. Expression profiles of p63, p53, surviving and hTERT in skin tumors. J Cutan Pathol. 2004;31:544-9.

24. Dornelas MT, Rodrigues MF, Machado DC, Gollner AM, Ferreira AP. Expression of cell proliferation and apoptosis biomarkers in skin spinocellular carcinoma and actinic keratosis. An Bras Dermatol. 2009;84(5):469-75.

25. Khodaeiani E, Fakhrjou A, Amirnia M, Babaei-Nezhad S, Taghvamanesh F, Razzagh-Karimi E, Alikhah H. Immunohistochemical evaluation of p53 and Ki67 expression in skin epithelial tumors. Indian J Dermatol. 2013 ;58(3):181-7.

26. Lee YS, Teh M. p53 expression in pseudoepitheliomatous hyperplasia, keratoacanthoma, and squamous cell carcinoma of skin. Cancer. $1994 ; 73(9): 2317$

27. Ruhoy SM, Guinee DG, Nuovo G. Squamous cell carcinoma arising in association with verruca vulgares and HPV-2: a clinicopathologic study with p16 and p53 immunohistochemical studies and human papillomavirus in situ hybridization studies. Appl Immunohistochem Mol Morphol. 2014 Apr;22(4):253-61.

28. Drvar DL, Lipozenčić J, Sabol I, Mokos ZB, Ilic I, Grce M. Human papillomavirus status in extragenital nonmelanoma skin cancers. Clin Dermatol. 2014 Mar-Apr;32(2):248-52

29. Wood GS, Bagheri M, Gordon E, Larson PO, Snow S : Nonmelanoma skin cancers: basal cell and squamous cell carcinomas. In: Abeloff M, ArmitageJO, Niederhuber JE, Kastan BM, McKenna WG(eds): Clinical Oncology, Elsevier Churchill Livingstone, 2004, 1589-1609

30. Opara KO, Jiburum BC. Skin cancers in albinos in a teaching Hospital in eastern Nigeria - presentation and challenges of care. World J Surg Oncol. 2010;8 (73):1-6

31. Rodust PM1, Stockfleth E, Ulrich C, Leverkus M, Eberle J. :UV-induced squamous cell carcinoma--a role for antiapoptotic signalling pathways. Br J Dermatol. 2009 ;161 Suppl 3:107-1

32. Naruke Y, Nakashima M, Suzuki K, Matsuu-Matsuyama M, Shichijo K, Kondo H, Sekine I. : Alteration of p53-binding protein 1 expression during skin carcinogenesis: association with genomic instability. Cancer Sci. 2008;99(5):946-51.

33. Gao L: p53 alterations in human skin. Acta Universitatis Upsaliensis, Uppsala 2001, pp1-53

34. Queille S1, Luron L, Spatz A, Avril MF, Ribrag V, Duvillard P, Hiesse C, Sarasin A, Armand JP, Daya-Grosjean L. Analysis of skin cancer risk factors in immunosuppressed renal transplant patients shows high levels of UV-specific tandem CC to TT mutations of the p53 gene. Carcinogenesis. 2007 Mar;28(3):724-31

35. Batinac T, Zamolo G, Jonjić N, Gruber F, Petrovecki $\mathrm{M}, \mathrm{p} 53$ protein expression and cell proliferation in nonneoplastic and neoplastic proliferative skin diseases, Tumori, 2004, 90(1):120-127 
36. Sakiz D, Turkmenoglu TT, Kabukcuoglu F. The expression of p63 and p53 in keratoacanthoma and intraepidermal and invasive neoplasms of the skin. Pathol Res Pract. 2009; 205(9): 589-94.

37. Rapini RP:Epithelial neoplasms. In: Rapini RP(ed):Practical Dermatopathology. First edition, Elsevier, 2005, pp 233-25

38. KuboY, Murao K, Matsumoto K, Arase S: Molecular carcinogenesis of squamous cell carcinomas of the skin. J Med Invest; 2002, 49:111-117

39. Tomas D: Apoptosis, UV-radiation, precancerosis and skin tumors. . Acta Med Croatica. 2009;63 Suppl 2:53-8.

40. Nikolić MM: Prekancerozne dermatoze, maligni tumori, pseudoepiteliomske hiperplazije i paraneoplastične dermatoze. U: Lalević-Vasić B, Medenica LJ, Nikolić M: Dermatovenerologija sa propedevtikom, Savremena administracija, Beograd, 2008, str 281- 299

41. Lober BA, Lober CW: Actinic keratosis is squamous cell carcinoma. J Am Acad Dermatol; 2000, 93:650-655

42. Gleich T, Chiticariu E, Huber M, Hohl D. Keratoacanthoma: a distinct entity; Exp Dermatol. 2016 Feb; 25(2): 85-91
43. Florence ME, Massuda JY, Soares TC, Stelini RF, Poppe LM, Bröcker EB, Metze K, Cintra ML, de Souza EM. p53 immunoexpression in stepwise progression of cutaneous squamous cell carcinoma and correlation with angiogenesis and cellular proliferation. Pathol Res Pract. 2015 Oct;211(10): 782-8.

44. Stratigos AJ, Kapranos N, Petrakou E, Anastasiadou A, Pagouni A, Christofidou E, Petridis A, Papadopoulos O, Kokka E, Antoniou C, Georgala S, Katsambas AD. Immunophenotypic analysis of the p53 gene in nonmelanoma skin cancer and correlation with apoptosis and cell proliferation. J Eur Acad Dermatol Venereol. 2005 Mar;19(2):180-6.

45. Khullar G, Saikia UN, De D, Handa S, Das Radotra B. Predisposing factors and histopathological variants of cutaneous squamous cell carcinoma: Experience from a North Indian teaching hospital. Indian J Dermatol Venereol Leprol. 2016 May-Jun;82(3):273-8

46. Adinarayan M, Krishnamurthy SP. Clinicopathological evaluation of nonmelanoma skin cancer. Indian J Dermatol 2011;56:670-2 